\title{
Pretrial Diversion from the Criminal Process
}

Pretrial diversion is a formalized procedure authorized by legislation, court rule, or, most commonly, by informal prosecutorial consent, whereby persons who are accused of certain criminal offenses and meet preestablished criteria have their prosecution suspended for a three month to one year period and are placed in a community-based rehabilitation program. The rehabilitation program may include counseling, training, and job placement. If conditions of the diversion referral are satisfied, the prosecution may be nolle prossed or the case dismissed; if not, the accused is returned for normal criminal processing: ${ }^{1}$

The goals of pretrial diversion include: (1) unburdening court dockets and conserving judicial resources for more serious cases; (2) reducing the incidence of offender recidivism by providing an alternative to incarceration-community-based rehabilitation-which would be more effective and less costly than incarceration; and (3) benefiting society by the training and placement of previously unemployed persons. ${ }^{2}$

Pretrial diversion has been described as a "new model of social control."3 To ascertain what is novel about this practice, it should be placed in the context of and distinguished from established discre-

1. The National Pretrial Intervention Service Center in Washington, D.C., lists the three essential characteristics of pretrial diversion: (1) diversion of the accused out of the criminal process occurs before formal adjudication of guilt or innocence; (2) existence of formal eligibility and procedural standards for diversion; and (3) availability of community-based social and rehabilitative services for the accused immediately after divession. Interview with Arnold Hopkins, Director, September 1973 [hereinafter cited as Hopkins Interview]. See also National Advisory Commission on Criminal Justice Standards and Goars, Corrections 73 (1973) [hereinafter cited as Standards and Goals Report, Corrections].

Two premises underlie the characteristics of community-based rehabilitation. One is early crisis intervention. It is thought that intervention in the period shortly after arrest-"the peak moment of contrition and sense of guilt when an offender is most anxious to make amends and set things right"-is the most propitious time for rehabilitation. Testimony of Whitney North Seymour, Jr,, former United States Attorney, Southern District of New York, in Hearings on S. 3309 Before the Subcomm. on National Penitentiaries of the Senate Comm. on the Judiciary, 92d Cong., $2 d$ Sess. 30 (1972) [hereinafter cited as Hearings on S. 3309]. This bill subsequently became S. 798. See Hearings on S. $79 S$ Before the Subcomm. on National Penitentiaries of the Senate Comm. on the Judiciary, 93d Cong., Ist Sess. (1973) [hereinafter cited as Hear. ings on S. 79S]. Amended S. 798 passed the Senate on October 3, 1973. See the accompanying report, S. REP. No. 417, 93d Cong., lst Sess. (1973).

The other premise is that traditional correctional institutions have failed to rehabilitate and therefore an alternative approach using community resources is needed. STINDARDS AND Goals Report, CoRrecrions, supra at 74-77.

2. These goals have received general agreement. See, e.g., testimony of K. Mossman, Chairman of the Criminal Law Section of the American Bar Association, summarizing the goals of several pretrial diversion programs, in Hearings on $S$. 79S, supra note 1 , at 379 .

3. Robertson, Pretrial Diversion of Drug Offenders, 52 B.U. L. REv. 335, 337 (1972). 
tionary practices of noncriminal disposition or screening-out of accused persons before trial. ${ }^{4}$ Diversion represents a discretionary exercise and is often used synonymously with discretion..$^{5}$ Discretion to screen-out cases at the pretrial stage may be categorized according to whether it is exercised pursuant to formal or informal standards, and whether or not a supervised rehabilitation regime exists. ${ }^{6}$

The label of diversion may properly be reserved for dispositions pursuant to formal standards followed by supervised rehabilitation. Pretrial diversion provides, in principle, criteria for decisionmaking, background information on the accused prior to screening-out, and established liaisons with community service agencies. It is an attempt to standardize ad hoc procedures of an informal discretionary system. ${ }^{7}$ The practice of noncriminal disposition before trial is not novel, but its articulation and formalization in diversion are of recent vintage. ${ }^{\mathrm{s}}$

In 1967, the President's Commission on Law Enforcement and the Administration of Justice recommended the "early identification and diversion to other community resources of those offenders in need of treatment, for whom full criminal disposition does not appear required." Within a year two pioneering pretrial diversion programs,

4. These discretionary practices are of long standing among law enforcement officials. About one-half of all arrested cases are dismissed at the pretrial stage. PrEsident's Comm'N ON LAW Enforcement and Administration of Justice: The Challenge of Crime in a Free Society 133 (1967) [hereinafter cited as Crmie Commission Report]. See also W. Lafave, Arrest: The Decision to Take a Suspect into Custony (1965); McIntyre \& Lippman, Prosecutors and Early Disposition of Felony Cases, 56 A.B.A.J. $1154(1970)$.

5. Some of the reasons for the exercise of discretion to dispose of cases without trial are not unlike those for diversion. They include the high volume of court cases, the likelihood of conviction, severity of the sanction in relation to the offense charged, and availability of rehabilitative services. Kaplan. The Prosecutorial Discretion-A Comment, 60 Nw. U.L. Rev. 174 (1965). See F. Miller, Prosecution: The Decision to Charge a Suspect with a Crime (1970).

6. Informal screening-out without rehabilitation is the most common form of discretionary action. This includes police discretion and prosecutorial screening-out of trivial offenses. See, e.g., President's Comm'n on LAw ENForcenient and AdministratION OF JUSTICE, TASK FORCE REPORT: CORRECTIONS 5 (1967) [hereinafter cited as PresiDENT's CoRrections Report7; Goldstein, Police Discretion Not to Invoke the Criminal Process, 69 YALE L.J. 543 (1960).

Informal screening-out with rehabilitation is exemplified by referrals of accused persons suspected of being mentally ill and public drunks to treatment centers. See, e.g., Vera Institute of Justice, Programs in Criminal Justice Reform: Ten-Year Refort $1961-1971$, at 57 (1972).

Formal screening-out without follow-up social services for certain offenses sometimes has a statutory basis. For example, some states authorize dismissal of charges in worth. less check and shoplifting cases when restitution is offered. F. MILLER, supra note 5, at 272-73; Note, The Merchant, the Shoplifter and the Law, 55 MinN. L. REv. 825 (1971).

7. This reflects current reform proposals to structure and make visible discretionary action in all pretrial activities. See ABA ProJeCr on STANDARds for Criminal Justice, Standards Relating to The Prosecution Function and The Defense Function (1971) (Standards 2.5 and 3.8 of the Prosecution Function) [hereinafter cited as ProseCution and Defense Standards]. See also K. Davis, Discretionary Justice 225 (1969); Note, Restructuring the Plea Bargain, 82 YALE L.J. 286 (1972).

8. See, e.g. Statement of Sen. Q. Burdick in Hearings on $S, 3308$, supra note 1 , at 1.

9. CRIMe Commission RePort, supra note 4, at 134 . 
the Manhattan Court Employment Project ${ }^{10}$ and Project Crossroads in Washington, D.C., ${ }^{11}$ were established. ${ }^{12}$ They became models for "second-round" programs in seven cities funded by the United States Department of Labor in 1971.13 Within the past two years the ideal of pretrial diversion has been endorsed by public officials, ${ }^{14}$ the American Bar Association, ${ }^{15}$ national commissions, ${ }^{16}$ and professional law ${\text { organizations. }{ }^{17} \text { Federal }^{18} \text { and state legislation }}^{19}$ authorizing pretrial

10. Vera Institute of Justice, The Manhattan Court Employment Project: Finai Report (1972) [hereinafter cited as Manhattan Program Report].

11. National Committee for Children and Youth, Final Report: Project CrossRosds (1971) [hereinafter cited as Project Crossrosds RePorT].

12. The Citizens Probation Authority in Genesee County, Michigan, was established two years before the Manhattan Program and Project Crossroads. See Statement of Robert F. Leonard, Prosecuting Attorney, Genesee County, in Hearings on S. 798, supra note 1, at 410 [hereinafter cited as Leonard Statement]. However, because of the Michigan Program's limited scope and visibility, the later two programs garnered public attention and became models for new programs.

13. The programs are in Atlanta, Baltimore, Boston, Cleveland, Minneapolis, San Antonio, and the California Bay Area (Hayward, San Jose, Santa Rosa). Descriptive reports on the organization and operations of each of these programs were prepared in 1971 and 1972 by ABT Associates, Inc., Cambridge, Mass. [hereinafter cited as ABT Report on Atlanta, Baltimore, etc.]. Statistical information on these programs is found in ABT Associates, Inc., Pretrial Intervention Program: Second Interim Progress Report (1972) [hereinafter cited as ABT Progress Report]. Names and addresses of these seven programs, plus those of 13 others, are listed in the statement of R. Hughes, Chairman, ABA Commission on Correctional Facilities and Services, in Hearings on $S$. 79S, supra note 1, at 384-85. Between 1967 and 1972, the United States Department of Labor spent over $\$ 5$ million on pretrial diversion. Information on funds expended by state governments, private foundations, and the Law Enforcement Assistance Administration (LEAA) is not available. Hopkins Interview, supra note 1 .

14. See address by Associate Justice Rehnquist before the National Conference on Criminal Justice, sponsored by LEAA, Washington, D.C., January 25, 1973. In an address to the National Conference on Corrections, former Attorney General John Mitchell noted that "in many cases society can best be served by diverting the accused to a voluntary, community oriented correctional program instead of bringing him to trial." The Minneapolis Star, Dec. 6, 1971, at 13b.

15. See ABA Commission on Correctional Facilities and Services, Coordination Bulletin No. 17, June 1973; Prosecutron and Defense Standards, supra note 7 (Standards 3.8(a) of the Prosecution Function and 6.1(a) of the Defense Function urge each party to explore the availability of noncriminal disposition, including early diversion into community-based rehabilitation programs, especially for first offenders).

16. STANDARDS AND Goals REPORT, CORRECTONs, supra note 1 , at 95.

17. These include the National District Attorneys Association, the American Correctional Association, and the National Council on Crime and Delinquency. See Statement of $\mathrm{R}$. Hughes, Hearings on $S$. 798 , supra note 1 , at 382 . The Judicial Conference of the United States supports amended bill S. 798. S. REP. No. 417, supra note 1 , at 11 .

18. See Hearings on S. 79S, supra note 1 , and Hearings on S. 3309, supra note 1.

19. Connecticut is the only state that has a statute authorizing pretrial diversion of nonaddicts. Conn. Public Act No. 73-641, June 12, 1973. Section I states:

There shall be a pre-trial program for accelerated rehabilitation of persons accused of a crime, not of a serious nature. This act shall not be applicable to persons accused of a class A, class B, or class C felony. Such program may be invoked by a state's attorney or prosecuting attorney in his discretion with respect to an accused who, such attorney believes, will probably not offend again and who has no previous record of conviction of crime. . . Any such defendant shall appear in court and shall be released to the custody of the commission on adult probation for such period, not exceeding two years, and under such conditions as the court shall order. . . . If such defendant satisfactorily completes his period of probation, he may apply for dismissal of the charges against him and the court, on finding such satisfactory completion, shall dismiss such charges. 
diversion for nonaddict ${ }^{20}$ offenders has been introduced and state supreme courts have promulgated enabling rules. ${ }^{21}$ Today, pretrial diversion programs exist or are about to sprout in some 50 metropolitan areas. ${ }^{22}$

As these programs proliferate and mature, basic issues of policy and law ${ }^{23}$ surface with respect to the scope, procedures, objectives, and dangers of pretrial diversion, as well as to its role in relation to other agencies and reforms ${ }^{24}$ of the criminal process. Much of the literature consists of descriptive reports of particular programs with inadequate evaluation research. ${ }^{25}$ There has been little critical analysis of the kind

The statute was drafted without reference to, and probably in ignorance of, pretrial diversion programs then operating in New Haven and Hartford. The program staffs and local criminal justice officials did not know of the existence of the statute until several months after it was passed. Interview with Daniel Ryan, Executive Director, New Haven Pretrial Services Council, October 1973.

Similar legislation has been proposed in Massachusetts. See Senate Bill No. 1592, An Act Establishing a Procedure to Divert Selected Offenders from the District Courts to Programs of Community Supervision and Service (1970).

20. Federal and state legislation authorizing the diversion of narcotic addict offenders has been in existence for some time. For a survey of these statutes, see Robertson, supra note 3, at 337; Note, Addict Diversion: An Alternative Approach for the Criminal System, 60 GEO. L.J. 667, 677 (1972). All the pretrial diversion programs cited in note 13 supra deal with nonaddict accused offenders.

21. New Jersey Rules of Criminal. Practice 3.28 (Defendant's Diversionary Program) adopted by the New Jersey Supreme Court, October 7, 1970; Pennsylvania Rules OF CRIMINal Procedure 175-85 (Accelerated Rehabilitative Disposition) adoptcd by the Pennsylvania Supreme Court, May 24, 1972. These are the only existing enabling court rules expressly addressed to pretrial diversion.

22. At the National Conference on Pretrial Intervention held in Atlanta on September 19-21, 1973, there were representatives from about 50 cities which have or are about to have pretrial diversion programs of some kind. See Nordheimer, Pretrial Diversion Held Helpful in Cutting Crime, N.Y. Times, Sept. 21, 1973, at 44, col. 1.

23. Pretrial diversion presents, in principle, many legal issues. The National Pretrial Intervention Service Center is undertaking a comprehensive study of these legal issues. Hopkins Interview, supra note 1. Preliminary analyses can be found in Skoler, 1'rotection of Civil Liberties of Pretrial Intervention Clients, address in Symposium on Therapeutic Intervention Between Arrest and Trial as an Effective Alternative to Standard Court Processing, American Psychological Association Convention, Montreal, August 30, 1973 [hereinafter cited as Skoler 1973]; Skoler, Who's in Charge Here: Legal Issues in Pretrial Diversion, address to Pretrial Diversion Workshop, St. Paul, Minn., June 27, 1972 [hereinafter cited as Skoler 1972]; State of Michigan Office of Criminal Justice Programs, Deferred Prosecution and Criminal Justice: A Case Study of the Genesee County Citizens Probation Authority (1972), reprinted in Hearings on S. 798, supra note 1 , at 486-98; Note, supra note 20.

24. Pretrial diversion is only one of a number of current reform efforts in the pretrial phase of criminal proceedings. Professor Daniel J. Freed of the Yale Law School has distinguished two categories of pretrial reforms: person reforms, which deal with the person of the accused such as pretrial release, bail, and diversion; and procedural reforms, which deal with the procedures for handling a criminal case, such as the restructuring of plea bargaining, speedy trial, and reorganization of the prosecution and defense functions. D. Freed, Pretrial Project Prospectus, 1973 (unpublished paper). For an overview of pretrial "person reforms," see Note, Administration of Pretrial Release and Detention: A Proposal for Unification, 83 YALE L.J. 153 (1973).

25. See, e.g., the ABT Reports on the "second-round" programs, supra note 13; Metropolitan Dade County, Pretrial Intervention Project: 18-Month Report (1973); Hudson County Pretrial Intervention Project \& Vocational Service Center, Program and Procedures (1973); State of Michigan Office of Criminal Justice Programs, Deferred Prosecution and Criminal Justice: A Case Study of the Genesee County Citizens Pro- 
that is required prior to the permanent funding and institutionalization of these programs. ${ }^{26}$

This Note deals with pretrial diversion of nonaddict, adult accused offenders. ${ }^{27}$ It describes four aspects of pretrial diversion-the diverted population, the "intake" decision, social intervention, and the termination decision-and discusses accompanying issues of law, policy, and evaluation research. ${ }^{28}$ Two main questions are raised: (1) Are current pretrial diversion programs effective in achieving their stated goals?

bation Authority (1972), reprinted in Hearings on $S .798$, supra note 1, at 440-517. Sce also National Pretrial Intervention Service Center, Technical Assistance Handbook on Pretrial Intervention Techniques and Action Programs (1973); National District Attorneys Association, Manual on Pretrial Screening and Diversionary ProGRAMS (1972). Existing studies of pretrial diversion are primarily descriptive rather than analytical. See Brakel \& South, Diversion from the Criminal Process in the Rural Community, 7 AM. CrIM. LAw Q. 122 (1969); Carter, The Diversion of Offenders, 36 FED. Prob. 31 (1972); Harlow, Diversion from the Criminal Justice System, 2 Crime \& Deling. Lit. 136 (1970).

26. Pretrial diversion has been described as a "practice in search of a theory." Vorenberg \& Vorenberg, Early Diversion from the Criminal Justice System, 1972 (unpublished paper, Harvard Law School). An expanded version has appeared in PRISONERS IN Ayrerica 151 (L. Ohlin ed. 1973). Citations in this Note are to the original unpublished paper. Other analytical and occasionally skeptical commentaries are found in National advisory Commission on Criminal Justice Standards and Goals, Courts 32-41 (1973) [hereinafter cited as Standards ANd Goals RePORT, Couits]; STANDARDS AND Gonls ReporT, CoRrections, supra note 1, at 73-97; Newman, Corrections of the Future: Some Paradoxes in Development, in Collected PAPERs: Conference on Corrections in Context 3 (D. Baker ed. 1972); D. Freed, E. De Grazia, \& W. Loh, The New Haven Pretrial Diversion Program: A Preliminary Evaluation, June 1973 (unpublished report to the New Haven Pretrial Services Council; copy on file in Yale Law School Library) [hereinafter cited as Freed]; S. Messinger, The Year 2000 and the Problem of Criminal Justice, address to the Conference on Criminal Justice in Chicago, June 24, 1973 (unpublished paper, School of Criminology, University of California, Berkeley); R. Nimmer, Alternatives to Prosecution: Diversion from the Criminal Justice Process, 1973 (unpublished paper, American Bar Foundation, Chicago).

27. This Note thus is confined to pretrial diversion of accused adults without problems of drug abuse (see note 20 supra), alcoholism (see R. NIMMER, Two MILLION

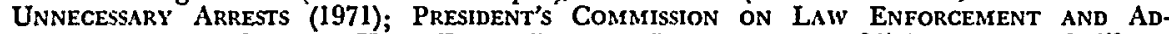
Ministration of JUStICE, TASK Force Report: DRunkenness (1967)), or mental illness (see E. De Grazia, Report on Pretrial Diversion of Accused Offenders to Community Mental Health Treatment Programs in Washington, D.C., 1971 (unpublished report to National Institutes of Health)). Juvenile diversion is also excluded. For a consideration of some of the issues in juvenile diversion projects, see AMERICAN Correctional Association, Juvenile Diversion: A Perspective (1972); R. Lemert, Instead of Court: Diversion in Juvenile Justice (1971); National INSTITUTE of LAw ENForcement and Criminal Justice, New Approaches to Diversion and Treatment of Juvenile OFFENDERS (1973).

28. The data for this Note were drawn from program reports, supra notes 13 and 25; observations of the New Haven, Manhattan, and Crossroads programs; and personal interviews conducted between January and September 1973.

The description of program procedures relies to a great extent on personal observations rather than the programs' own published accounts. A program's own published accounts often reflect a designer's ideal conception of how a program should operate instead of how it in fact operates under everyday pressures.

To avoid repeated documentation of the same references, the sources for the following materials will not be footnoted again: Statistical data on the Manhattan, Crossroads, and New Haven programs are drawn from the evaluation reports, supra notes 10 , 11 , and 25, respectively. Description of procedures of the "second-round" programs come from the ABT reports, supra note 13, and statistical data from the ABT Progress Report, supra note 13 , based on a survey of 1,866 participants processed by the seven programs as of fall 1972. 
(2) What kinds of controls, based on legal and policy considerations, exist or should be built into operational procedures to safeguard basic rights of program participants against potential abuses of discretion by criminal justice officials and program staff in the course of pretrial diversion?

\section{Diverted Population}

\section{A. Eligibility Criteria}

All programs have formal eligibility criteria established either by the prosecutor if the program was initiated by and is under the auspices of his office, or by the program staff in agreement with the prosecutor if the program is administratively independent. An accused who fails to meet any one of the following criteria may be disqualified:

Residency. The accused must be a resident of the city or county in which the program operates.

Age. There is usually a minimum age requirement of 16 or 17 years and there may also be an upper age limit of 25 to 45 years. ${ }^{20}$

Charge. This criterion varies from program to program. ${ }^{30}$ In general, new programs begin cautiously, limiting admission to those charged with misdemeanors. As they mature and gain the confidence of criminal justice officials, the criteria are expanded to cover nonviolent felonies. ${ }^{31}$ Motor vehicle law violators, narcotics addicts, and prostitutes are normally excluded.

Prior arrests. Some programs admit only accused first offenders; ${ }^{32}$

29. Some age requirements are: in Project Crossroads and the Boston program, 16 to 26 years: in Manhattan, 16 to 45 years; in New Haven, 16 years with no upper limit; in Baltimore, 16 to 18 years. Program participants are generally young; the median age in the Manhattan program is 19. Most participants in all programs are under 25.

30. Project Crossroads admits only those accused of one of 12 specific misdemeanor offenses. Interview with James Davis, Director of Project Crossroads, May 1973. On the other hand, the New Haven program has an open-ended rule allowing admission of a person charged with any offense up to and including a class $D$ felony. New Haven Pretrial Services Council, Diversion Program Eligibility Criteria, 1972. See Conn. Public Act No. 73-641, June 12, 1973.

31. Project De Novo in Minneapolis began by accepting only accused misdemeanants but now also accepts a limited number of accused felons. In the first three years of the Manhattan program, 65 percent of the participants were charged with misdemeanors, 30 percent with felonies, and 5 percent with violations. The use of misdemeanor-felony labels may be misleading because there is no uniform classification of offenses. Thus, though the Atlanta program admits a large number of accused felons, most of them are accused of possession of marihuana, an offense which in other juris: dictions may constitute only a misdemeanor.

Property offenses are the most frequent charges. In the "second round" programs, 50 percent were accused of larceny and theft; 10 percent with automobile theft; 10 percent with misconduct; and 10 percent with drunkenness or marihuana possession.

32. Project Crossroads is one example. 
others will admit persons with a record of one prior misdemeanor conviction; ${ }^{33}$ and still others require only that the accused be a "nonhabitual offender." ${ }^{34}$ Programs usually begin with accused first offenders and gradually broaden their eligibility standards to encompass those with prior records. ${ }^{35}$

Unemployment. Since the Department of Labor which funded the early programs emphasized a manpower approach to rehabilitation, subsequent programs also adopted under- or unemployment as a condition for eligibility. However, this requirement is not consistently enforced. ${ }^{36}$

Guilty plea. A controversial condition for eligibility for pretrial diversion is the requirement of a plea of guilty ${ }^{37}$ or an acknowledgment of "moral responsibility" for the charged offense. ${ }^{38}$ Admission of guilt is said to be necessary for successful rehabilitation and for the protection of the prosecutor's case. ${ }^{39}$ From a therapeutic viewpoint,

33. The San Antonio and Boston programs permit one prior misdemeanor conviction. However, about 70 percent of the participants in the San Antonio program and 42 percent in the Boston program have no prior adult record.

34. See Leonard Statement, supra note 12. The New Haven program allows "one previous felony or three previous misdemeanor convictions during the past five years." See note 30 supra.

35. This develops over time as programs earn the confidence of local prosecutors. Also, first offender statutes in some jurisdictions obviate the need for pretrial di. version of such individuals. In California, first offender misdemeanor charges are expunged upon completion of summary probation. Consequently, "judges are inclined to feel that with this option available, many individuals do not require the services of an intervention program." ABT Report on Project Intercept (California Bay Area programs), supra note 13 , at I-14. Nonetheless, 42 percent of California program participants were accused first offenders. New York has "adjournment in contemplation of dismissal" whereby prosecution of accused first offenders on marihuana possession or violation charges is deferred for a certain period, and if no additional offenses are committed during this time, the initial charges are dismissed. As a result, the Manhattan program no longer diverts persons accused of violations. Interview with Ennis Olgiatti, Director, Manhattan program, April 1973.

S. 3309 would exclude from eligibility those accused of a crime of violence or convicted of a prior offense punishable by more than one year imprisonment. Hearings on S. 3309, supra note 1 , at 5 . Following widespread criticism of these restrictive criteria in the hearings on S. 3309 , S. 798 was amended to abolish all requirements as to charge and prior arrests. In fact, it now provides no standards whatsoever regarding eligibility for pretrial diversion. The government attorney is authorized but not required to divert, and he has sole discretion to determine which accused persons are "eligible." Hearings on $S .798$, supra note $1, \S 3(1)$.

36. In the "second round" programs, about one-fifth to one-half of the participants were fully employed during the year preceding arrest and pretrial diversion.

37. See Skoler 1972, supra note 23 , at 14 .

38. See Hearings on $S$. 79S, supra note 1 , at 497 (Citizens Probation Authority (CPA) program). Amended $S$. 798 apparently adopted the CPA program prccedure of requiring an "informal acknowledgment of personal responsibility" instead of a formal guilty plea. This "meets the needs of rehabilitation without raising the possibility of unnecessary delays inherent in the formal pleading procedure." S. REP. No. 417, supra note 1 , at 14 .

39. This is the position of the Department of Justice. See letter of R. Erickson in Hearings on $S .3309$, supra note 1 , at 139 , and testimony of M. McKevitt in Hearings on $S .79 S$, supra note 1 , at 397. 
repentance may be necessary for rehabilitation. ${ }^{40}$ But the premise of criminal justice is that guilt is established after trial. The purpose of diversion before trial is precisely to spare certain accused individuals the burden of criminal processing, including the necessity to enter a plea. Indeed, when an accused is in custody and unrepresented by counsel, any plea spurred by the promise of pretrial diversion is arguably coerced and invalid, not because the promise is improper, but because the accused under those circumstances is too susceptible to inducement. ${ }^{41}$

As a practical matter, even if pretrial diversion does not imply a legal finding of guilt, ${ }^{42}$ it "implicitly assumes guilt." 43 Program staff consider it inhibitory to counseling to maintain a presumption of innocence that both parties know is questionable. In fact, most participants "freely and without being asked admit to their participation in the alleged offense." 44 As a precondition for pretrial diversion, it has been recommended that "the facts of the case establish that the defendant committed the alleged act." 45

\section{B. Eligibility and Prosecutability}

Inflexible and restrictive eligibility provisions may undermine program effectiveness. ${ }^{46}$ Although the varying needs, resources, and attitudes of criminal justice agencies in different localities make it impractical to construct detailed model eligibility criteria, it may be useful to propose an approach to guide the formulation of those criteria.

In most jurisdictions, prosecutability is determined informally. About one-half of all arrests are disposed of outside the criminal process. ${ }^{47}$ Some charges are dismissed, some nolle prossed, and some

40. Citizens Probation Authority sees it as a "psychological necessity" and "essential to the "reality therapy" approach used for reforming anti-social conduct." Hearings on $\$$. 79S, supra note 1 , at $505 \mathrm{nn} .163-64$. Others are not convinced that confession is a prerequisite to rehabilitation. See testimony of K. Mossman, id. at 390 .

41. "But with the inducement of a lighter sentence dangled before him, the sincerity of any cries of mea culpa becomes questionable." Scott v. United States, 419 F.2d 264, 271 (D.C. Cir. 1969).

42. See p. 842 infra.

43. Nimmer, supra note 26 , at I. In fact, one researcher found an implicit assumption of guilt underlying all practices in a metropolitan criminal court. A. Buumberg, Criminal Justice (1967).

44. Hearings on S. 798, supra note $\mathrm{I}$, at $505 \mathrm{n} .164$ (Gitizens Probation Authority program).

45. Standards and Goals Report, Corrections, supra note 1, at 96 (Standard 3.1(3)(g)).

46. An example in point is the Narcotics Addict Rehabilitation Act which, due to severe eligibility criteria, proved to be virtually useless in the diversion of addict defendants. Testimony of former United States Attorney W. N. Seymour, Jr., in Hearings on $S .3309$, supra note $\mathrm{I}$, at 31 .

47. CRIMe Commission Report, supra note 4, at 133. 
reduced in exchange for a plea of guilty. The reasons for these actions include the nature of the offense, the weight of the evidence, the personal characteristics of the arrestee, and the amount of resources available to the prosecutor. These variables, taken together, can be differentially weighted and entered into an equation producing an index of prosecutability. ${ }^{48}$ The accused can be placed on a continuum or scale ranging from low to high priority of prosecution. This scale could then be divided into three categories of prosecutability, though the locations of the dividing lines may vary in different jurisdictions: (l) those at the lower end would be screened-out at the pretrial stage; (2) those in the intermediate section would be diverted before trial; and (3) those at the upper end would have top prosecution priority.

Existing eligibility criteria normally state only the upper limit of the second section (e.g., misdemeanor charge and no more than one prior conviction); the lower limit is left undefined. Consequently there is the risk that those who should be screened-out are funneled into pretrial diversion.

Failure to define clear boundaries at both ends of the pretrial diversion eligibility section has endangered realization of one of diversion's stated goals-efficient use of resources in the criminal justice process. One of the often stated advantages of pretrial diversion is the reduction of court docket congestion. ${ }^{4}$ This goal seems more ideal than real. Pretrial diversion saves court time only if, in its absence, the accused would go to trial. But most pretrial diversion cases, given the nonserious nature of the charges, would have been disposed of by negotiation and plea rather than trial on the merits.50

The caseload burden on the system is not significantly reduced so

48. A prosecutability score is currently computed for every accused individual appearing in the Superior Court of the District of Columbia. A social psychological scale has been adopted that measures severity of the charged offense which, combined with data on an accused's past record and other background factors, yields a composite score that determines priority of prosecution. However, this scale is used only for determining prosecution priority, not pretrial diversion eligibility. Interview with Charles Work, chief assistant United States Attorney, District of Columbia, April 1973.

49. See note 2 supra.

50. The only available data that support this observation come from a preliminary study, based on a small sample, by Freed, supra note 26, at 76. However, interviews with prosecutors (note 120 infra), public defenders (note 77 infra), and judges (notes 68-69 infra) in different jurisdictions indicated that only infrequently would an accused, charged with an offense and possessing a record similar to that of the ordinary program participant, go to trial. No available data support the contrary view. Indeed, pretrial diversion may take the same or more time than ordinary disposition by negotiation and plea. The prosecutor and court still retain responsibility for both the initial diversion decision and final disposition. The accused must still appear in open court at those times and for interim continuance motions. See note 56 infra. If there is an unfavorable termination, there must be rearraignment and the negotiations must begin anew. 
long as programs divert a minimal fraction of all arrested cases. ${ }^{51}$ Increasing the numbers diverted relieves the burden but may also strain program resources and reduce program effectiveness. 52

\section{Intake Decision}

The decision to divert an accused person results from an interplay of discretionary decisions by the program and different agencies of the criminal process. To appraise this aspect of a pretrial diversion program, it is necessary to look at the relationships among and the perceptions of the program staff and local criminal justice officials, principally prosecutors, judges, and defense counsel.

\section{A. Program staff}

A common procedure of pretrial diversion programs not affiliated with the prosecutor's office is staff inspection of the daily arrest lists at the police detention center and selection, on the basis of the available information on record, of those who satisfy prima facie the eligibility criteria ${ }^{53}$ These persons are then personally interviewed by the program screener. ${ }^{54}$

Diversion programs use one of two types of screening procedures. In the one-stage screening procedure, such as that used in New Haven,

51. In New Haven, for example, less than two percent of all arrested persons are diverted. Freed, supra note 26, at 63 . Amended S. 798 envisions pretrial diversion of 2,000 persons per year out of a federal district court caseload of 44,000 per year, or about 5 percent. S. REP. No. 417 , supra note 1 , at 9 .

52. A distinctive advantage of pretrial diversion programs at present is the ample funding that permits low counselor-participant caseload ratios. See note 122 infra. A substantial increase in intake without a corresponding increase in program resources may result in the situation that most probation departments and juvenile court staffs are now facing: overburdened caseloads and low staff morale.

53. Not all eligible persons are in fact screened for pretrial diversion. For example, the Manhattan program does not operate on weekends, so persons arrested at that time have no opportunity to be diverted. The New Haven program estimates that one-half of the city's arrested population is not screened because program staff are not on duty weekdays during court session hours or on weekends. Freed, supra note 26. at 28.

54. The purpose of the detention interview, according to the New Haven program's written procedures which are patterned after those of the Manhattan program, is to explain to the accused the nature of the program; the right to counsel before making a decision whether to accept pretrial diversion if granted; the absence of a presumption of guilt or innocence; and the lack of any guarantee of dismissal of charges upon successful program completion. New Haven Pretrial Services Council, Diversion Program Statement to Participants, 1972. In practice, interviews take place in a crowded, noisy detention cell, last only a few minutes, and essentially give the screener an opportunity to "size-up" the accused rather than discuss the foregoing four points. Most accused persons, for their part, are simply anxiouts to get out of detention. Interviews with New Haven program participants indicated that many had no real understanding of what pretrial diversion was about at the time they agreed to participate. 
the program screener recommends to the prosecutor pretrial diversion for the accused immediately after the detention interview. ${ }^{55}$ If granted, a continuance is requested from the court, and the accused is released to the care of the program. In the two-stage procedure, the screener seeks an interim one or two week continuance in order to enable the program to conduct further interviews and investigations of the candidate before rendering an admission decision. ${ }^{56}$

The diversion decision is significantly affected by the type of screening procedure. Under the one-stage procedure the decision is usually made under harried circumstances: the accused decides on the spot without full comprehension of the program; the prosecutor consents or rejects with only minimal time to examine the accused's case; defense counsel is left out of the decisionmaking; the screener is unable to discuss the case with other program staff so there is no internal check or review of his decision. ${ }^{57}$ The two-stage process provides additional time to minimize these risks.

\section{B. Prosecutors}

The key figure in pretrial diversion is the prosecutor. His influence over intake and disposition largely determines the character and effectiveness of a program.

Since a prosecutor is considered to have almost unfettered discretion

55. In principle, a careful joint evaluation by prosecutor and screener of the needs of the accused and the circumstances of the charge is contemplated. In reality, the prosecutor barely has time to peruse the arresting officer's report and ustally has to decide on the spot whether or not to grant pretrial diversion. Seriousness of the alleged offense and prior record, not rehabilitative potential, are the determinants of his decision. Freed, supra note 26, at 27.

56. This is the procedure used in the Manhattan program. The two-stage procedure used in Project Crossroads is different in two important respects. In Crossroads, during the one week interim continuance, it is the prosecutor, not the program staff, who makes the investigation of the accused's background. The party with this information has an advantage in the ensuing negotiations. Also, after the interim continuance, the Crossroads procedure provides for an informal conference among prosecutor, defense counsel, and the accused. This hearing procedure ensures participation by defense counsel in the diversion decision. In Manhattan, after the program has investigated the accused further, the screener approaches the prosecutor to negotiate for pretrial diversion. Defense counsel plays no role in the diversion decision.

57. Interviews with screeners of the New Haven and Manhattan programs reveal that, within the scope of the eligibility criteria, there is still room for considerable individual discretion. One screener, for example, may pay attention to an accused's "attitude"; if it is negative, the accused is disqualified even though all eligibility criteria are satisfied. Another screener who is "street-wise" may rely on knowledge of facts about an accused not revealed in the record in deciding whether or not to recommend admission. Because differences in discretionary judgments are inevitable, it is necessary to build controls into the screening process to guard against arbitrariness. Some controls may be attained by requiring screeners to record the reasons for rejecting a candidate after the detention interview or interim continuance investigation, with review of that decision by a program staff supervisor. 
to prosecute, ${ }^{58}$ it is widely assumed that he has almost unfettered discretion to divert as an incidence of that power. Any suggestion of limiting that discretion is denounced by prosecutors as an improper subversion of their traditional authority. ${ }^{59}$

Programs initiated by and affiliated with the prosecutor's office are naturally under his control. Community-based programs, administratively independent of any criminal justice agency, often are equally

58. Discretion whether or not to prosecute is rooted in English common law. The Attorney General of England had unfettered power to decide whether to prosecute in criminal cases, subject only to the control of the 'High Court of Parliament when there was an abuse of discretion. Regina v. Allen, 121 Eng. Rep. 929 (Q.B. 1862). In federal courts, the prosecutor "is clothed with the power and charged with the duties of the Attorney General in England under the common law." United States v. Brokaw, 60 F. Supp. 100, 101 (S.D. Ill. 1945). In the Confiscation Cases, 74 U.S. (7 Wall.) 454, 457 (1868), the prosecutor was held to have exclusive discretion to enter a nolle prosequi at any time before the jury was impanelled. Rule 48a of the Federal Rules of Criminal Procedure now requires judicial consent to a request for nolle, but no criteria exist for the exercise of judicial discretion in ruling on a motion to nolle, nor is the prosecutor required to state his reasons for seeking a nolle. State prosecutors also possess the common law powers of the Attorney General of England in the absence of limiting statutes. See, e.g., People v. Covelli, 415 Ill. 79, 112 N.E.2d 156, 160 (1953).

Policy justifications also exist for the prosecutor's discretionary authority. See CrImE Commission Report, supra note 4, at 133; K. DAvis, supra note 7, at 188-91; Prosecurion AND Defense Standards, supra note 7 . at 64 (Prosecution Standard $\$ 2.5$ ); Baker, The Prosecutor-Initiation of Prosecution, 23 J. CRIM. L. \& C. 770 (1933); Baker, The Prosecuting Attorney: Legal Aspects of the Office, 26 J. Crim. L. \& C. 647 (1935); Ferguson, Formulation of Enforcement Policy: An Anatomy of the Prosecutor's Discretion Prior to Accusation, 11 Rutgers L. REv. 507 (1957); Comment, Prosecutorial Discretion in the Initiation of Criminal Complaints, 42 S. CAL. L. REv. 519 (1969). The courts have been reluctant to intrude in the prosecutor's discretion except in instances of patent abuse. It would be "sheer impertinence" and "contrary to settled judicial tradition" to do so. Howell v. Brown, 85 F. Supp. 537, 540 (D. Neb. 1949). Chief Justice Burger, then judge in the District of Columbia Circuit, noted:

Few subjects are less adapted to judicial review than the exercise by the Executive of his discretion in deciding when and whether to institute criminal proceedings .... or whether to dismiss a proceeding once brought.

Newman v. United States, 382 F.2d 479, 480 (D.C. Cir. 1967); accord, United States v. Boyle, 338 F. Supp. 1025 (D.D.C. 1971).

59. Indicative of this prosecutorial sentiment were the reactions to the two federal pretrial diversion bills. The initial bill, S. 3309, authorized (1) both the program director and the prosecuting government attorney to recommend an eligible accused individual to the committing officer (United States magistrate or district judge) for pretrial diversion, and (2) the district judge to release any accused individual into a program even when he fails to meet the eligibility criteria, if such release would promote rehabilitation. Hearings on $S$. 3309, supra note 1, $\$ \S 5 \& 6$ (b). Prosecutors otherwise favorable to pretrial diversion criticized the bill for allowing the court and program director a say in the diversion decision. W. N. Seymour, Jr., former United States Attorney for the Southern District of New York, testified that:

Although a judicial officer should have some role in approving the plan to defer

prosecution in order to assure against abuses, it is a mistake to change the fundamental division of responsibility by shifting the decision on whether or not to prosecute the case from the prosecutor to the court.

Id. at 32. See also Statement of Deputy Attorney General R. Erickson, id. at 139.

As a result, subsequent bill $S$. 798 defined an "eligible individual" for pretrial diversion as one who is recommended by the government attorney. Hearings on $S$. $79 S$, supra note $1, \S 3(1)$. Even with this change, there were reservations about possible judicial intrusion. As one prosecutor testified, "I am still a prosecutor, and I do not like judges fooling around with my discretion, and that is really what it is all about." R. Leonard, id. at 406. See also Statement of J. McKevitt, Assistant Attorney General, id. at 396. 
under prosecutorial control. In the New Haven program, for instance, a screener's recommendation for pretrial diversion is rarely rejected by the prosecutor. This is because the screeners deliberately select and recommend only those accused individuals whom they expect the prosecutor will approve. They have learned to predict prosecutorial preferences. ${ }^{60}$

In more established programs the relation with the prosecutor may be more adversarial. Manhattan program screeners are fairly aggressive in advocating the pretrial diversion of eligible individuals. They often "appeal" an assistant district attorney's rejection of a diversion recommendation to his superior or to the arraignment judge. Nonetheless, they recognize that the program's viability depends on prosecutorial grace, and they are cautious not to often recommend eligible cases that they anticipate the assistant prosecutors will veto. ${ }^{61}$

\section{Judges}

Judicial reticence to interfere with the prosecutor's discretion extends to pretrial diversion. Standard 2.2 on diversion procedures of the National Advisory Commission on Criminal Justice Standards and Goals proposes that "the decision by the prosecutor not to divert a particular defendant should not be subject to judicial review."62 Amended S. 798 authorizes a United States magistrate or district judge to release an "eligible individual" into pretrial diversion, but "eligible individual" is defined as an accused person recommended by the government attorney. ${ }^{63}$

Some programs are authorized by enabling state court rules. In New Jersey, the state supreme court must approve a program and judges are authorized to defer criminal proceedings pending pretrial diversion upon recommendation by the program administrators with consent of the prosecutor. ${ }^{64}$ The authority of a judge when the prosecutor denies consent is not defined. Criminal procedure rules adopted by the Pennsylvania Supreme Court authorize a hearing before a judge on a motion for pretrial diversion requested by the prosecutor or defense counsel. ${ }^{05}$ Again, the judge is involved in the decisionmaking only

60. Freed, supra note 26, at 43. The same observation has been made of the De Novo program in Minneapolis. Nimmer, supra note 26, at 115.

61. Interviews with Manhattan program screeners and assistant district attorneys, April 1973.

62. Standards and Goals Report, Courts, supra note 26, at 40.

63. Amended S. 798, 92d Cong., 2d Sess. $\$ \$ 5$ \& 3(1) (1973). See note 1 supra.

64. N.J. R. CRIM. P. 3.28(a), 3.28(b); see note 21 supra.

65. PA. R. CRIM. P. 175, 178; see note 21 supra. The district attorney of the Accelerated Rehabilitative Disposition program (ARD) in Philadelphia screens all arrested cases and subpoenas eligible persons to appear for an informal hearing before 
after the prosecutor has selected and decided whom he will divert. ${ }^{86}$

Judicial interest and participation in pretrial diversion programs vary in different jurisdictions but generally appear to be limited. In some jurisdictions pretrial diversion is exclusively a matter of prosecutorial discretion and " $[t]$ he only role played by the judge is in granting the motion for continuance . . . or for dismissal of charges." ${ }^{67}$ In others, judges who are basically sympathetic to the idea of pretrial diversion nonetheless feel no need to review the prosecutor's or program screeners' discretionary judgments and are disinclined to assume a more active role. ${ }^{68}$ Judges are more knowledgeable about pretrial diversion when a program is organized as a component of the court, but even then they defer to the prosecutor's discretionary control..$^{69}$ In one program most of the participants are directly referred by the court. $^{70}$ Yet upon favorable termination, the same judges refuse to dismiss charges and grant instead summary probation after a nolo contendere plea. ${ }^{71}$

\section{Defense counsel}

There are two stages in the pretrial diversion process in which participation by defense counsel is important-at intake to assist the ac-

a special ARD judge in the Court of Common Pleas. Although defense counsel is present at the hearing, he intervenes only after the prosecutor has made the diversion decision. Diversion at the initiative of defense counsel is infrequent. Interview with $D$. Vinikoor, assistant district attorney, Philadelphia, September 1973. See Philadelphia ARD Program: Grant Application to Governor's Justice Commission, July 1973 (Office of the District Attorney, PhiladeIphia).

66. Two interests are involved in pretrial diversion: the interest of society in deterrence, and the interest of the accused in rehabilitation. Judicial scrutiny of the diversion decision after the prosecutor has decided whom to divert may safeguard only the first interest. Paradoxically, prosecutors do not seem to mind if a judge, in the interests of deterrence, refuses to approve a diversion recommendation. However, if a judge in the interests of rehabilitation were to order diversion over the objection of the prosecutor, this would be denounced as improper judicial encroachment. So long as the enabling court rules and proposed statutes da not give the judge a role in the initial diversion decision, or do not authorize a judge to review the prosecutor's decision, there may be no occasion for judicial safeguards of an accused's interest in rehabilitation. However, California courts have at least indirectly shown a willingness to protect the rehabilitative interest. See People v. Tenorio, 3 Cal. 3d 89, 473 P.2d 993, 89 Cal. Rptr. 249 (1970) (statute restricting court's power to strike from complaint factual allegation which, if true, would change penalty, held unconstitutional as violative of California's constitutional separation of powers).

67. Testimony of W. Henschel, Hearings on $S$. 3309, supra note 1 , at 56, regarding the De Novo program in Minneapolis.

68. Interviews with Judges Adorno and Quinn of the New Haven Sixth Circuit Court, March 1973.

69. Interview with Chief Judge $H$. Greene of the Superior Court of the District of Columbia, February 1973. Project Crossroads began as an independent program but later was incorporated into the social services department of the Superior Court.

70. In the California programs, no screening in the police detention cells is allowed and the staff cannot recommend persons for diversion. Instead, the judge at his discretion directly refers accused persons to the program. See ABT Report on California Bay Area programs, supra note 13.

71. See note 129 infra. 
cused in making an informed decision, and at rearraignment or disposition upon unfavorable termination.

Program procedures often state that prospective participants shall have the opportunity to consult with counsel, ${ }^{72}$ if desired, before agreeing to pretrial diversion. ${ }^{73}$ With some exceptions, ${ }^{74}$ this does not commonly occur in reality. ${ }^{75}$ Some of the underlying reasons are inadequate communication and misperceptions between program staff ${ }^{76}$ and defense counsel. ${ }^{77}$ Defense counsel is not even mentioned in amended bill S. 798.7s

Most accused persons probably could be allocated, without disagreement among criminal justice officials, into the three categories of (1) screen-out, (2) pretrial diversion, and (3) prosecution. However, the boundaries of the second category may be imprecisely drawn. Exercise of discretion is greatest in cases falling in the two marginal zones, and

72. Right to counsel in criminal proceedings where the accused faces possible im. prisonment, even on misdemeanor charges, is guaranteed by the Sixth Amendment. State ex rel. Argersinger v. Hamlin, 407 U.S. 25 (1972). Some commentators have recommended representation by counsel at all pretrial negotiations with the prosecutor. Standard 2.2 of Procedure for Diversion Programs stresses "the offender's right to be represented by counsel during negotiations for diversion and entry and approval of the agreement." STANDARds AND Goals RePort, Courts, supra note 26, at 39 .

73. See, e.g., New Haven Pretrial Services Council, Diversion Program Statement to Participants, 1972, supra note 54.

74. The Philadelphia ARD program and Project Crossroads, unlike other programs, involve defense counsel. Their procedures make the presence of defense counsel necessary because the diversion decision is made at a hearing at which a judge or prosecutor presides. See notes $56 \& 65$ supra.

75. This is also the conclusion of Arnold Hopkins, supra note 1, and Daniel Skoler, Director of the ABA Commission on Correctional Facilities and Services, Washington, D.C., Interview held September 1973.

Most program participants are indigent and do not have counsel at intake. If a participant is unfavorably terminated and rearraigned on the initial charge, the court then usually assigns counsel. But counsel at that point typically has no information regarding the participant's program performance. In the absence of counsel at intake, programs submit periodic performance reports only to the prosecutor's office. The lack of information may prejudice subsequent defense efforts. Interview with $M$. Lewis, chief public defender, New Haven Sixth Circuit Court, March 1973.

76. Screeners in the New Haven and Manhattan programs expressed apprehension that their "independent status" in the eyes of the prosecutor would be jeopardized by close association with defense counsel. The fear that public defense counsel might "dump" marginal cases on the program to relieve their own caseloads was another deterrent to collaboration. Interviews in March-April 1973.

77. Public defenders and legal aid attorneys appear sympathetic but unmotivated to intervene in the diversion decision. New Haven public defenders, for example, believed the stakes involved for program participants were small given the nature of the charges and prior arrest records, and saw no urgent reason for intervening. Alternately, when larger stakes were involved, they were reluctant to seek diversion for the accused unless confident the accused would be favorably terminated. Otherwise, their bargaining position would be weakened and subsequent defense efforts prejudiced. Interviews with Ifessrs. M. Lewis and $\mathrm{H}$. Cruse, public defenders, New Haven Sixth Circuit Court, April 1973. Similar views were expressed by L. Stiller, public defender, Superior Court of the District of Columbia, April 1973. Legal aid attorneys in New Haven, in agreement with the prosecutorial view, opposed converting the diversion decision into a quasi-adversary proceeding. Advocacy on their part was seen as threatening the informal cooperation between the program and the prosecutor's office. Interviews with Messrs. Howard Geminer and Jon Silbert, April 1973.

78. Amended S. 798, 92d Cong, 2d Sess. (1973). See note 1 supra. 
it is to these, as well as to cases that appear to be in the second category, that assistance of counsel should attach at the intake stage. At the boundary between the diversion and the prosecution categories, there are those who are willing, formally eligible, and conceivably might benefit from pretrial diversion, but to whom the prosecutor denies consent and insists on criminal processing. This prosecutorial decision is not challenged or reviewed, and program staff generally avoid possible confrontations by anticipating prosecutorial response and avoiding marginal cases. ${ }^{70}$

At the boundary between the diversion and the screen-out categories, there are those formally eligible but for whom pretrial diversion may not be in their best legal interest. Insufficient or improperly seized evidence, triviality of charge, ${ }^{80}$ or any of a number of grounds may render probable an outright dismissal, a suspended sentence, or a minor fine. Risk of unfavorable termination may also offset the benefits of pretrial diversion. ${ }^{81}$ In these instances the accused needs assistance of counsel to make an informed choice.

The requirement of a guilty plea or an acknowledgment of "moral responsibility" as a prerequisite for program participation points out the need for assistance of counsel for those in the diversion category. At issue is the presumption of legal, not factual, innocence. ${ }^{82}$ An admission of guilt to a program counselor does not have the same legal consequences as a formal guilty plea in open court. A factor in the diversion decision should be legal guilt. If, in the judgment of defense counsel, the accused could be found guilty, he should be recommended for pretrial diversion assuming he is otherwise eligible and willing. If the accused could not be found guilty regardless of his guilt or inno-

79. See Freed, supra note 26, at 43; Nimmer, supra note 26, at 112, 115 .

80. One-half of all misdemeanor arrests are "essentially violations of moral norms or instances of annoying behavior." President's CoMmission ON LAW ENFORCEMENT AND ADMinistration of JUSTICE, TASK Force Report: JUVENILE DELINQUENCY ANd Youth Crime 10 (1967).

81. Some public defenders in the District of Columbia felt that unfavorable termination from Project Crossroads would prejudice defense efforts when prosecution is reinstated, because there would be reduced hope of negotiating a favorable plea. Interview with L. Stiller, Washington D.C., April 1973. Indeed, current prosecutorial policy is to give top priority to the prosecution of unfavorably terminated participants. Interview with Charles Work, chief assistant United States Attorney, Washington, D.C., April 1973.

82. See p. 833 supra. It is important that the presumption of legal innocence be maintained. Whether an individual participant admits to a program counselor actual guilt or responsibility is legally inconsequential. So Iong as the prosecutor agrees to treat all statements made in pretrial diversion, including the fact of participation, as privileged material and inadmissible in evidence, there is no danger of self-incrimination. Some programs have informal agreements of this kind with the prosecutor. The aba Project on Minimum Standards for Criminal Justice, Standards Relating to Pleas of Guilty $\$ 3.4$ (1967) [hereinafter cited as Standards Relating to Pleas of Guicty], recommends the exclusion of all pretrial negotiations from use at subsequent trials. 
cence in fact, he should not be recommended for pretrial diversion unless he expressly desires it and is eligible. This procedure would help ensure that cases which warrant dismissal do not become pretrial diversion cases.

\section{E. Control of discretion}

Once a prosecutor consents to the establishment of a pretrial diversion program, fairness and social policy would dictate that his discretion to divert, unlike his discretion to prosecute prior to the establishment of the program, should be subject to judicial control.

Pretrial diversion can be seen both as an exchange and as a sentencing process. As in plea bargaining there is a legitimate exchange of tactical concessions to the mutual advantage of defense and prosecution. ${ }^{83}$ However, instead of negotiating on a case-by-case basis, pretrial diversion formalizes the exchange a priori and packages it for allocation on a mass basis.

But pretrial diversion constitutes more than an exchange. It is a sentencing activity by nonjudicial personnel. Upon the initiative of program staff and with the consent of the prosecutor, the accused is sentenced to a term of probation before trial without effective intervention of defense counsel or judge.

The almost universal hostility to pre-plea judicial intervention, whether in plea bargaining ${ }^{84}$ or pretrial diversion, ${ }^{85}$ reflects a conception of both as tactical exchanges rather than as sentencing processes. ${ }^{86}$ A decision to divert, however, is a functional equivalent of a sentence to pretrial probation. ${ }^{87}$ Pretrial diversion encroaches on judi-

83. In Brady v. United States, 397 U.S. 742,752 (1970), plea bargaining was justified in terms of the "mutuality of advantage" for defense and prosecution.

84. See, e.g., Standards Relating to Pleas of Guilty, supra note 82, $\$ 3.3$; Whitc, A Proposal for the Reform of the Plea-Bargaining Process, 119 U. PA. L. REv. 439, 452 (1971). Court decisions condemning judicial intervention are summarized in Note, supra note 7 , at 287 n.5. However, a survey of prosecutors in 30 states found that about one-third indicated the judge was in fact involved in some phase of the plea bargain. Note, Guilty Plea Bargaining: Compromises by Prosecutors to Secure Guilty Pleas, 112 U. PA. L. REv. 865, 905 (1964). See also McIntyre \& Lippman, supra note 4 , at 1157.

85. See pp. $839-40$ supra.

86. See Note, supra note 7 , at 287.

87. Pretrial diversion has been seen as "mere per se shifting of selected offenders from one form of probationary supervision (i.e., post-conviction) to another form of the same (i.e., pre-prosecution probation)." Leonard Statement, supra note 12, in Hearings on $S .79 S$, supra note 1 , at 411 . Amended $S .798$ proposes the use of federal probation officers for the pretrial diversion staff. Amended S. 798, 92d Cong., 2d Sess. $\$ 9(1)(b)$ (1973). See note 1 supra. Some programs are currently operated by state probation departments. See Nassau County Probation Department, Operation Midway, 1973. Even in programs operated independently of probation, it is recognized that "the majority of the cases handled by the [pretrial diversion] project could normally be handled through the probation unit." ABT Report on Baltimore, supra note 13, at 29. 
cial sentencing authority. Although there is no formal adjudication of guilt before sentence, most programs tend to proceed as if the accused is guilty in fact and in need of rehabilitation. Favorable termination, therefore, preempts the duty of the judge to adjudicate and sentence. It should be incumbent upon judges to claim responsibility for the diversion decision or, at least, to oversee the discretionary decisions of prosecutor and program staff.

Merely substituting decisionmakers will not protect against arbitrary discretion. Change in pretrial diversion procedure must also be effected. There should be a hearing before a judge ${ }^{8 s}$ if and whenever there is disagreement among prosecutor, program staff, and defense counsel regarding admission of borderline cases. This prediversion hearing, modeled after a sentencing hearing, would be an open advocacy proceeding. After informal argument by prosecutor and defense counsel, and presentation of a presentence report ${ }^{89}$ on the accused by the program staff, the judge would rule on admission. ${ }^{20}$ This procedure would help ensure sentencing due process ${ }^{91}$ in the pretrial diversion decision.

\section{Social Intervention}

Upon waiver of the right to speedy trial and the statute of limitations, and in some instances after plea of guilty or acknowledgment of "moral responsibility" for the charged offense, prosecution is deferred, and the accused enters the three to 12 month pretrial diversion program. ${ }^{92}$ It is characteristic of these programs that the staff consist pri-

88. Current programs which include a hearing give the judge only a limited role. For example, the role of the Philadelphia ARD hearing judge, as in plea bargaining, is limited to a superficial oral examination of the accused to ensure that his acceptance of diversion was voluntarily and intelligently made. The hearing is not a forum for challenging the prosecutor's decision. See note 65 supra.

89. On the presentence report, see generally Note, The Presentence Report: An Empirical Study of Its Use in the Federal Criminal Process, 58 Geo. L.J. 451 (1970). Programs with a two-stage screening procedure normally prepare a background report dur. ing the interim continuance period. See p. 837 supra.

90. The same judge, of course, would not preside in the subsequent trial if the accused is unfavorably terminated. This would be consistent with Rule 32 (c) of the Federal Rules of Criminal Procedure which forbids disclosure of the presentence report to the presiding judge until after the defendant has pleaded or been found guilty.

91. There has been growing concern for the procedural regularity of sentencing procedures. See Mempha v. Rhay, 389 U.S. 128 (1967) (sentencing found to be a "critical stage" in a criminal proceeding and right to counsel granted); Oyler v. Boles, 368 U.S. 448 (1962) (defendant must have notice and opportunity to be heard prior to sentencing). See also Pugh \& Carver, Due Process and Sentencing-From "Mapp" to "Mempha" to "McGautha," 49 Texas L. REv. 25 (1970).

92. In all programs the staff may and often do request an additional continuance of 30 to 60 days if warranted by the rehabilitative needs of the accused. See, e.g, ABT Reports, supra note 13 . 
marily of paraprofessionals, including ex-offenders, drawn from the same community from which program participants come. ${ }^{93}$ The services provided vary across programs but the mainstays are counseling and job placement.

The objectives of counseling in pretrial diversion appear nebulous. During the first two years of the Manhattan program, counselors and participants often did not know what was expected of them; at one point there were 10 different counseling plans. ${ }^{94}$ "[D]ismissals were being granted to participants who spent 12 weeks being quiet, obedient, and uninvolved." 95 Even today, each counselor pursues his own counseling approach; individual and group counseling methods are tried on and off seemingly without any guiding theory. ${ }^{96}$

Whereas Manhattan counselors are generally more analytically oriented, aiming to change basic social attitudes, the New Haven and Crossroads counselors concentrate on improving elementary social functioning: ${ }^{97}$ In most programs the weekly counseling is little more than a "rap session." It is in effect a probationary-type of supervision and control-though with more sympathy and attention than that provided by the average overburdened probation officer-mixed ad hoc with some social services, vocational counseling, and personal advice on how to cope with the exigencies of urban living. ${ }^{98}$ Regular attendance is perhaps the main objective measure of good performance.99

93. One of the goals of the Manhattan program was to demonstrate that rehabilitation can be operated by paraprofessional ex-offenders. Some feel that successful use of such staff in itself justifies pretrial diversion programs. Interview with Leon Leiberg, director of Parole Corrections Project, American Correctional Association, September 1973.

94. Manhattan Program Report, supra note 10 , at 37.

95. Id.

96. In the "second round" programs, 58 percent of the participants received no group counseling. (Programs vary greatly: In Atlanta, 86 percent were involved in group sessions; in Minneapolis, 2 percent.) Overall, in the seven programs, 39 percent of participants received in excess of 10 hours of individual counseling during the three month diversion period.

97. The New Haven staff believe that behaviors and attitudes built up over a lifetime will not be altered by paraprofessional counseling in three months. Project Crossroads counselors defined their task as teaching the participant "to manipulate the system," i.e., teaching how to ride a city bus, apply for welfare, become a knowledgeable consumer, and so forth.

98. In addition to counseling and job placement, other services include informal tutorials, formal remedial education, and referrals to outside sources for psychological, medical, or legal assistance. In the "second round" programs, about 72 percent of participants are male, 40 percent are white; 40 percent black (though some programs, such as the one in Baltimore, are predominantly black), and 13 percent are Mexican-Americans; most have completed high school. Programs differ in the extent of services provided. Thus, while Project Crossroads offers a General Education Diploma, the Boston and San Antonio programs have no in-house remedial education and no referrals to outside educational institutions even though their participants have the lowest cducational levels among the "second round" programs.

99. Repeated failure to attend counseling appointments is one of the most frequent grounds for unfavorable termination. See note 124 infra. 
The second main rehabilitation tool is job placement. ${ }^{100}$ Program staff generally serve as brokers for channeling the accused to community or state employment agencies and job training positions. ${ }^{101} \mathrm{Job}$ development by the program staff itself is infrequent.

The effectiveness of social rehabilitation is difficult to assess because of the variation from program to program and the absence of clearly defined measurement standards. ${ }^{102}$ It is important to keep in mind that the delivery of social services-counseling, job placement, and remedial education-is an immediate goal that must be distinguished from the basic criminal justice goals of pretrial diversion-recidivism reduction, stigma avoidance, and resource conservation. These social services are or should be means to these other ends. Otherwise, a pretrial diversion program would be evaluated as any other agency engaged in counseling, employment placement, or tutoring. ${ }^{103}$

The principal justification and appeal of pretrial diversion is reduction of offender recidivism which underlies rising crime rates. ${ }^{104}$ Most program participants are accused of property offenses, ${ }^{105}$ and recidivism is generally more prevalent among those arrested for property offenses than for crimes of violence. ${ }^{106}$

Rearrest rates for favorably terminated participants over a period

100. When participants are mostly school-age youth, as in the Baltimore program, the rehabilitation emphasis is on counseling rather than job placement.

101. In the "second round" programs, 57 percent of the participants needing employment were placed and 29 percent dropped their new jobs before completion of their diversion tenure.

102. Ideally, the criterion of effectiveness might be the degree of correlation between individual needs and characteristics on the one hand, and different rehabilitation alternatives on the other. However, very little is yet known about how different kinds of individuals respond to different kinds of correctional treatment. See Crime Commission Report, supra note 4, at 141. Some forms of rehabilitation, such as individual and group counseling, involve subjective judgments, and uniform standards for evaluating their effectiveness are as yet unavailable.

103. There is a tendency for program staff to become so engrossed in the delivery of social services that the distinction between immediate and ultimate goals is blurred. One program administrator stated that "the ultimate goals of the project include assisting those accepted in finding stabilized and productive employment." Berger, The New Haven Pretrial Diversion Program: A Preliminary Report, December 31, 1972, at 2 (unpublished memorandum, New Haven Pretrial Services Council).

104. Public endorsements of pretrial diversion invariably make this claim. See note 2. supra. S. REP. No. 417 accompanying amended S. 798 states:

The real benefit of pretrial diversion is the final result: The individual who has completed a program of pretrial diversion is much less likely to commit another crime than the individual who goes through the criminal justice system in the normal way.

S. ReP. No. 417, supra note 1 , at 7 .

105. See note 31 supra.

106. See D. Graser, The Effectiveness of a Prison and Parole System 4144 (1964). Research of criminal careers shows a 90 percent probability that an individual convicted of larceny, auto theft, burglary, or robbery, will be rearrested for one of these four offenses. Blumstein \& Larsen, Madels of a Total Criminal Justice System, 17 Operations Research 224 (1969). Former United States Attorney W. N. Seymour, Jr., noted that "recidivism is least likely to occur among persons guilty of at least certain forms of violent crime." Hearings on S. 3309, supra note 1 , at 32 . 
of three to 12 months range from between one and three percent in some programs, to an average 10 percent in the "second round" programs, ${ }^{107}$ and 15.8 and 22.2 percent in the Manhattan and Crossroads programs. ${ }^{108}$ In support of pretrial diversion, these figures are frequently compared with the much higher recidivism rates of those convicted and sentenced to probation or jail. ${ }^{109}$ However, since different populations are compared, these differences are not very meaningful. ${ }^{110}$

In the absence of control groups no conclusions can be drawn about the effectiveness of pretrial diversion in reducing recidivism. Only the Manhattan and Crossroads programs have employed matched controls. The control groups showed a recidivism rate of 31.9 and 45.7 percent, respectively, or about twice that of favorably terminated participants. ${ }^{111}$ Aside from the methodological invalidity of these control groups, ${ }^{112}$ even if it is assumed that program participation reduces recidivism, it is not known what element or elements of the total program package produced the effect. ${ }^{113}$ Until there are data from experi-

107. Recidivism data for different programs are summarized in Hearings on $S$. $79 S$, supra note 1 , at 385 .

108. Manhattan Program Report, supra note 10, at 47 (over a pericd of 12 months); Project Crossronds Rerort, supra note 11 , at 35 (over a period of 15 months).

109. For example, Senator Burdick estimated about two-thirds of all those prosecuted and convicted are rearrested. Hearings on $S .798$, supra note 1 , at 389.

110. Those sentenced are more serious and higher risk cases than those diverted before trial, so it is not surprising that the former population manifests a higher recidivism rate. A more meaningful comparison would be between those diverted and those informally screened-out before trial, since these two populations are more alike. Indeed, since property offenders are generally known to have high recidivism rates, a claimed recidivism rate of one or three percent taxes credulity. Planned social interventions simply are not that effective. These programs must be unusually successful or they are selecting such low-risk participants that recidivism is unlikely even without pretrial diversion.

111. Minhattan Program Report, supra note 10, at 47; Project Crossronds Report, supra note 11 , at 35.

112. "Control" groups in the Manhattan and Crossroads programs consisted of those who underwent normal criminal processing a few weeks prior to the start of the programs and who would have been eligible for pretrial diversion under the formal cligibility criteria had the programs been in operation at that time. They were matched by age, offense charged, and residence with a nonrandom sample of favorably terminated participants. These "controls" cannot be compared with the diverted sample because the former, unlike the latter, did not undergo screening interviews by the program staff. Because diverted participants are deliberately screened for potential program success, they are noncomparable with the controls. This kind of deliberate selection process is common in all programs. The Citizens Probationary Authority concedes, for example, that it is "highly selective" and admits only "persons for whom the probability of recidivism is low." Hearings on $S$. 79S, supra note 1, at 445 . Unless there is random assignment of eligible candidates to control and diversion conditions, any observed differences in recidivism rate may be explained either by a genuine effect of program participation or by the artifact of sample selection.

113. The lower recidivism rate of favorably terminated participants compared to controls-assuming no differences in initial selectivity between the two groups-may be due to (1) the rehabilitative services, (2) the avoidance of the trauma of prosecution and criminal stigmatization, or (3) the interaction of both factors. If the first factor is principally responsible for reduced recidivism, then it would not matter if the re- 
ments with random assignment of individuals to different comparison conditions, ${ }^{114}$ the claim of recidivism reduction remains an article of faith.

The avoidance of stigmatization from criminal processing by channeling the accused into rehabilitation is another rationale for pretrial diversion. ${ }^{115}$ For a first offender or middle class professional, the social consequences of a criminal sanction-social ostracism and possible foreclosure of economic opportunities-are very real. ${ }^{116}$ However, few

habilitative services were provided before or after trial. It would be interesting to compare recidivism rates between pretrial diversion programs and experimental probation or correctional programs (which have highly motivated corrections officers, low caseloads, and facilities and services equal to those of pretrial diversion programs). For an overview of some of these experimental approaches, see STANDARDS AND GoALS REPORT, CORRECTIONS, supra note 1 , at $221-46$, $311-40$. If the second factor produces the effect, the full panoply of rehabilitative services need not be delivered at all, at least to some participants.

In terms of a research design, future evaluation should compare the recidivism rates of four groups:

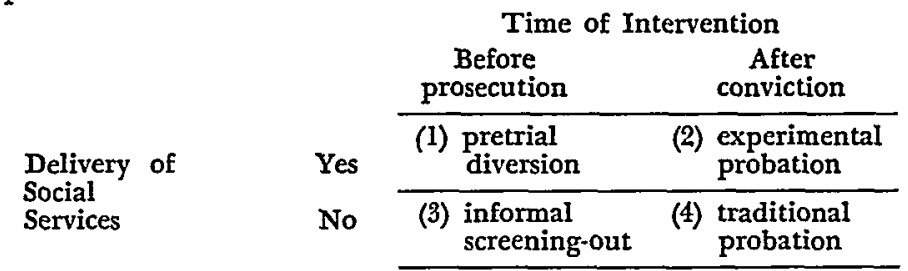

Present evaluation studies, their methodological shortcomings aside, have compared recidivism rates between groups 1 (low rate) and 4 (high rate). To use the logic of analysis of variance, these studies have examined only the "interaction effect" between the factors of rehabilitative services and avoidance of prosecution. They have neglected to examine the "main (column) effect" of avoidance of prosecution (comparing, specifically, the recidivism rates of groups 1 and 2), and the "main (row) effect" of rehabilitative services (comparing, specifically, the recidivism rates of groups 1 and 3 ). These proposed "main effect" comparisons could help pinpoint what, if anything, makes pretrial diversion effective in reducing recidivism, and how a program may be streamlined to attain that goal more efficiently.

114. The directors of the New Haven, Crossroads, and Manhattan programs expressed, in interviews, strong moral and legal objections to the random assignment of eligible accused persons to experimental (pretrial diversion) and control groups. Without delving into the ethical and legal problems of social experimentation, certain facts should be kept in mind: (1) Pretrial diversion programs do not have an overburdened caseload and they process a very small fraction of a jurisdiction's pool of accused offenders, see note 51 supra. (2) Under current screening procedures, considerable randomness and arbitrariness already exist, e.g., not screening persons arrested on weekends or during certain weekday hours, see note 53 supra. Explicit randomness may be no more undesirable than randomness from carelessness or arbitrary discretion that deprives eligible persons of the opportunity for pretrial diversion. (3) Similar experimentation in other areas of corrections has been proposed and carried out, see Crime' Commission RePort, supra note 4, at 260.

115. For studies in stigmatization, see Deviance: Studies in the Process of Stigmatization and Societal Reaction (S. Dinitz ed. 1969).

116. For lower or working class persons, a criminal sanction may have only limited social consequences. A British study found that for the common nonhabitual offender, typically poor, unskilled, and unemployed, "the [social] impact of conviction is directly related to the quality of life that went before," and "for many, stigma was at most a minor difficulty compared with the problem of getting a living at all." Sec J. Martin \& D. Webster, The Social Consequences of Conviction 203, 204 (1971). 
programs admit accused first offenders exclusively; many have a sizeable minority with prior convictions. For the accused already stigmatized, formal diversion into rehabilitation need not be confined to the pretrial stage. ${ }^{117}$

Comparison of per capita costs of pretrial diversion ${ }^{118}$ and of incarceration $^{119}$ and probation is often made to support claims of saved costs and efficient use of scarce judicial resources. Although the former costs less the comparison is misleading. Most pretrial diversion participants, if they had not been diverted, probably would not have been sentenced to prison. ${ }^{120}$ Probation, in contrast to pretrial diversion, is claimed to be a less effective rehabilitation process. The difference, if true, could be explained by unequal resources: Pretrial

117. The scope of this Note is confined to pretrial diversion. However, diversion could and sometimes does occur after trial, though different appellations are then used. Statutes in some states provide for probation without conviction. See, e.g., MD. ANN. CODE art. 27, $\$ 641$ (Supp. 1973). Deferred sentencing statutes may also stay imposition of sentence pending a probationary period which, if satisfactorily completed, leads to a reduced or suspended sentence. See, e.g., MinN. Stat. ANN. $\$ 609.135$ (1973).

$A$ unique program that combines pre- and posttrial diversion features is Operation Midway of the Nassau County Probation Department. It admits primarily those charged with serious felonies. Unlike other pretrial programs, the district attorney plays a passive role in the screening process; he seldom vetoes a diversion recommendation. However, favorable termination does not preclude prosecution; in fact, most of the serious cases are prosecuted. Favorable termination then becomes a bargaining lever for a reduced or suspended sentence after conviction. This procedure is interesting in several respects. It enables one accused of a serious offense to receive pretrial rehabilitative services while the prosecutor retains full discretion to prosecute. The onus of punishment is reduced, though not the stigma of conviction, and thus defense counsel is moved to participate actively because the stakes involved for the accused felons are high. Cohen. Project Operation Midway, 1972; Nassau County Probation Department, supra note 87.

118. Per capita costs in the New Haven program are $\$ 691$; Manhattan program, $\$ 731$ for favorably terminated participants (\$1,518 for favorably and unfavorably terminated participants combined); Project Crossroads, \$506. See respectively, Freed, supra note 26, at 68; MANhattan Program Report, supra note 10, at 50; J. Holohan, Report of a Benefit-Cost ANalysis of Project Crossroads 10 (1971).

119. National average per capita costs of incarceration per year during 1965 were $\$ 3,613$ for juveniles, $\$ 1,966$ for adult felons, and $\$ 1,046$ for adult misdemeanants. Crime Conimission RePORT, supra note 4, at 161 .

Indeed, if cost-savings is a main goal, the diversion exit point should be pushed back to the police stationhouse. The breakdown of costs among different criminal justice agencies for processing an accused (averaged across all categories of offenses) is as follows: 67 percent to police costs; 20 percent to corrections; 11 percent to juvenile agencies; and 2 percent to the courts. PREsident's Commission on LAw ENFORCEMENT AND AdMinistration OF JUSTICE, TASK FORCE Report: The CouRts 6 (1967) [hereinafter cited as President's Courts REPORT]. Lodging pretrial diversion programs in the court arraignment stage results in savings to that component of the criminal justice system which already bears proportionately the smallest burden.

120. This observation is based only on data from a preliminary study and impressions of criminal justice officials. See p. 851 infra; cf. Skolnick, Social Control in the Adversary System, $11 \mathrm{~J}$. Conflict Resolurion 52 (1967). No evidence to the contrary has been found. Even if an eligible accused were prosecuted and convicted rather than diverted, it would be unusual if the jail sentence were as long as three months, the length of a pretrial diversion period. Interview with Paul Foti, Chief Prosecutor, New Haven Sixth Circuit Court. 
diversion costs three times as much per capita as probation ${ }^{121}$ and pretrial diversion staff have one-third the caseload of probation officers. ${ }^{122}$

It remains to be shown that court congestion is appreciably alleviated, and scarce resources conserved, by current pretrial diversion programs. At the present time one could infer that the system caseload remains unaltered but one more agency, with its own substantial budget, has been added to its processing. ${ }^{123}$

\section{Termination Decision}

Participants who fail to meet program obligations are unfavorably terminated and returned for possible prosecution on the original arrest charge either during or at the end of the pretrial diversion period. Those who perform satisfactorily are favorably terminated and recommended to the prosecutor for dismissal of charges.

In contrast to the detailed entry criteria there are no comparable standards defining satisfactory performance. In practice, the principal basis for unfavorable terminations in New Haven is "lack of cooperative attitude" demonstrated by the accused's absence from counseling sessions. ${ }^{124}$ In the "second round" programs, 60 percent of unfavorable terminations were based upon "chronic lack of cooperation" and "abscondance." These factors seem more important than rearrest. In many programs rearrest during the pretrial diversion period does not lead to automatic expulsion. One-third of rearrested participants in the "second round" programs were not expelled; in fact most of them later received recommendations that charges be dismissed.

About two-thirds of the participants in the Manhattan, Crossroads, and New Haven programs are favorably terminated. ${ }^{125}$ They tend to

121. Average per capita cost of probation for an adult felony offender in 1965 was $\$ 200$. PRESIDENT'S COURTS REPORT, supra note 119 , at 15 . The cost of diversion is discussed in note 118 supra.

122. About three-fourths of all misdemeanants on probation are supervised by pro. bation officers with a caseload of over 100. The recommended ideal caseload per probation officer is 35. Crime Commission Report, supra note 4 , at 167. The caseload per counselor in the Manhattan program ranges from 18 to 30 and in Project Crossroads from 25 to 30 . Interview with E. Olgiatti, supra note 35; Interview with J. Davis, supra note 30 .

123. Pretrial diversion might be an effective device for reducing pretrial detention. It offers indigents accused of minor offenses who are unable to post bond an al. ternative to jail pending arraignment or trial. No data are available on the effect on pretrial detention.

124. Freed, supra note 26, at 72. Programs usually give participants every benefit of the doubt. It takes repeated absences before an unfavorable termination is issued.

125. In the "second round" programs, the favorable terminations ranged from 34 to 84 percent, with an average of 76 percent. Such figures are not very meaningful 
be older, white, more educated, and female. ${ }^{126}$ Dismissal of charges against the favorably terminated appears to depend in part on the prosecutor's control over intake. If he consents to the pretrial diversion of only those he does not intend to prosecute fully, it is likely he will also consent to the dismissal recommendation. ${ }^{\mathbf{1 2 7}}$ Conversely, if the prosecutor diverts those he would have prosecuted but for the program's intervention, it is less likely that he would routinely agree to dismissal recommendations. ${ }^{128}$ From the prosecutor's viewpoint, he can assert control over the pretrial diversion process either at intake or at disposition. In the New Haven, Crossroads, and Manhattan programs, almost all of the favorably terminated receive dismissals. In the California programs, only one-third are favorably terminated and many of these are nonetheless returned for criminal processing. ${ }^{129}$

The unfavorably terminated are returned for prosecution presumably without prejudice. ${ }^{130}$ Court records of the unfavorably terminated in New Haven show that none went to trial. One-third had their cases nolle prossed and the rest received minor fines or suspended sentences upon a plea of guilty. ${ }^{131}$ During the first two years of Project Crossroads, one-half of the unfavorably terminated nonetheless had their charges dismissed.132 Thus, it appears that at least some of the

in the absence of standards defining satisfactory performance. The favorable termination rate can be artificially raised or lowered simply by admitting more lower or higher risk participants.

126. Freed, supra note 26, at 74. These characteristics associated with "good risk" have also been found to be reliable predictors of favorable termination in the Manhattan program. Interview with Franklin Zimring. Professor of Law, University of Chicago Law School, and consultant to the Manhattan program, May 1973.

127. The New Haven program has an informal understanding with the prosecutor that the latter will consent to pretrial diversion of only those accused persons whose charges will definitely be dropped upon favorable termination. Interview with Mark

Berger, former Dircctor, New Haven Pretrial Services Council, February 1973.

128. See description of Operation Midway, supra note 117.

129. In the California programs the staff can only report the participant's performance to the prosecutor and cannot make any disposition recommendation. Favorably terminated participants enter a nolo contendere plea and receive summary probation (10 days in San Jose, 30 days to one year in Santa Rosa) at the end of which, upon motion, the case may be dismissed and the record expunged at the court's discretion. Many favorably terminated participants in fact never get their record expunged. ABT Report on Project Intercept (California Bay Area programs), supra note I3, at I-12, II-44.

130. Public defenders interviewed in New Haven and the District of Columbia felt that unfavorable termination would be prejudicial to defense efforts in the subsequent prosecution and sentencing stages. They believed it was in the best defense interests of an accused not to enter pretrial diversion if the chances were high that he might be unfavorably terminated. Interviews with Messrs. H. Geminer, M. Lewis, H. Cruse, and L. Stiller, March-April 1973.

131. Freed, supra note 26, at 76.

132. Testimony of $J$. Trotter, former assistant director of Project Crossroads, in Hearings on S. 3309, supra note 1 , at 111 . At present, however, all unfavorably terminated participants from Project Crossroads are given priority in prosecution. Interview with C. Work, supra note 81 . 
accused in pretrial diversion would have been screened-out of the criminal process anyway in the absence of these programs.

Fairness would seem to require some procedural safeguards when a participant is unfavorably terminated and returned for prosecution. Programs normally terminate by issuing written notice to participant and prosecutor. ${ }^{133}$ Since pretrial diversion might be viewed as probation before trial, the requirement of a hearing before probation revocation would seem applicable to diversion. ${ }^{134}$ However, the full panoply of procedural due process rights is not necessary. Unlike the probationer who faces imprisonment, the pretrial diversion participant faces only prosecution and the possibility of imprisonment. A simple factual hearing at which the participant could present his case to the program director and possibly be given another chance-with informal evidentiary procedures and without counsel ${ }^{135}$-would afford sufficient protection.

\section{Conclusion}

The idea of pretrial diversion is appealing. It represents an attempt to structure and make visible the informal prosecutorial practices of noncriminal disposition. It also makes possible the early delivery of rehabilitation services on a formal rather than impromptu basis. And it offers the prosecution an alternative to its standard options of full criminal processing or informal screening-out without follow-up supervision.

However, unresolved doubts remain about other aspects of the concept, its practice, and program organization. First, some observers believe that pretrial diversion is bringing about "an ideological shift"136

133. Unfavorably terminated participants normally do not have an opportunity to consult with counsel until rearraignment for prosecution on the initial charge.

134. In Hahn v. Burke, 430 F.2d 100 (7th Cir. 1970), cert. denied, 402 U.S. 933 (1971), the court held that due process required a hearing before revocation of probation. The probationer's loss of freedom was found to outweigh "governmental in: terest in summary adjudication" and "the added state burden of providing a limited hearing." 430 F.2d at 104. But see Standard 2.2, Procedure for Diversion Programs, which relies on the prosecutor's discretion to treat the unfavorably terminated participant fairly, and dismisses the need for a hearing before reinstatement of prosecution. STANDARDS AND GoALS REPORT, CoURTS, supra note 26, at 39.

135. Mempha v. Rhay, 389 U.S. 128 (1967), held the Sixth Amendment required appointment of counsel in a state hearing revoking probation and imposing sentence because substantial rights were affected. In pretrial diversion the unfavorably terminated participant will have an opportunity for counsel at rearraignment on the original charge, and any further challenges to the termination could be raised at that time. Programs should, however, send participant progress reports to defense counsel as well as to the prosecutor.

136. Hopkins Interview, supra note 1. 
or "change in attitudes"137 among criminal justice officials from an emphasis on deterrence to one on rehabilitation. Data have yet to be collected to show whether any changes in outlook among prosecutors have produced any real changes in their decisionmaking. Programs may operate merely as outlets for preexisting dispositional tendencies. In terms of the three-category scale of prosecutability, it is incumbent upon the programs to show that the participants are recruited from the second (diversion) category, and not from the first (screen-out) or third (prosecution) categories. At present, the risk to public safety by the diversion of those who should be prosecuted is minimal; but the risk to program viability by the diversion of those who should be screened-out is great.

Second, present discourse on the benefits of pretrial diversion is politicized and value-laden with empirically unsubstantiated assertions. The claim of recidivism reduction needs to be tested by methodologically proper evaluation research. The claim of resource conservation is unconvincing. Other claimed benefits-stigma avoidance, decriminalization of certain offenses, reduction of pretrial detentionare plausible but unconfirmed.

Third, assuming that participants are drawn from the middle category of the prosecutability scale, and that programs achieve some of their stated goals, there remains the question whether current program procedures may infringe upon constitutional rights of the accused. Pretrial diversion in practice consists of discretionary judgments by prosecutors and program staff. Their intentions and good faith may be of the highest order, but that affords little comfort to traditions of due process. Without judicial and defense counsel intervention in the diversion decision to safeguard against potential abuses of discretion, there is the danger that the results of pretrial diversion-like those of the juvenile court which itself began as a diversion mechanism-may be found not to justify the risks taken with basic constitutional guarantees. ${ }^{138}$

Pretrial diversion, which began six years ago with two pilot programs, has become today a reform movement "well on its way to institutionalization."139 It is predicted that by 1987 there will be 150 pro-

137. Interview with Raymond Nimmer, research attorney, American Bar Foundation, September 1973.

138. See In re Gault, 387 U.S. I (1967).

139. Zaloom, in 4 CRim. Justice Newsletrer, October 15, 1973, at 4. The question whether pretrial diversion programs should be established, which depends upon whether they are found effective in attaining their purported objectives, should be distinguished from the question of where they should be established or lodged in the criminal 
grams diverting annually 150,000 persons before trial. ${ }^{140}$ But continued proliferation of pretrial diversion programs at this time is hard to justify. Existing programs must first meet the burden of showing that their promises have been or could be delivered. Otherwise, the practice of pretrial diversion, like "almost everything we do in the criminal field, is on the basis of faith."141

justice system, e.g., police stationhouse, court, or probation department. A "total systems planning" approach must also consider their relation to other on-going reformse.g., speedy trial or bail reforms-in the criminal justice process. For a description and critique of the present piecemeal approach, see Note, supra note 24 .

140. Summary address by Daniel Skoler to the National Conference on Pretrial In. tervention, Atlanta, September 21, 1973 (unpublished); see note 22 supra.

141. Vorenberg \& Vorenberg, supra note 26 , at 8. 